\title{
ECONOMY AND POWER TUNING AN IC ENGINE FOR LOWER CO 2 FOOTPRINT
}

\author{
Nikola Manev ${ }^{1}$, Dame Dimitrovski ${ }^{2}$, Zoran Mirakovski $^{2}$, Igor Jovčevski ${ }^{2}$ \\ ${ }^{1}$ Military Academy "General Mihailo Apostolski" - Skopje, University "Goce Delčev" in Štip, \\ Vasko Karangeleski bb, Skopje, Republic of North Macedonia \\ ${ }^{2}$ Faculty of Mechanical Engineering, "Ss. Cyril and Methodius" University in Skopje, \\ P.O. Box 464, MK-1001, Skopje, Republic of North Macedonia \\ manev.nikola@yahoo.com
}

\begin{abstract}
A b s t r a c t: Despite their harmful environmental impact, $96.5 \%$ of the heavy commercial vehicles sold in 2020 were diesel driven, which goes to shows that IC engines will stay in use with road vehicles for the foreseeable future. Integrating catalytic converters and other filtering solutions in the vehicle exhaust systems provides a partial reduction of these emissions, but a further reduction is a trade-off between the engine power output and the continuously demanding eco-standards. This paper provides an insight into the workings of the engine control unit (ECU), the sensors it draws data from as well as the actuators it controls. Additionally, it analyzes fuzzy-logic control and how changing the fuzzy-logic maps within the ECU offers opportunities for increased engine power output with better fuel economy. Having said that, this paper aims to achieve both of these requirements using the IC engine control principles and locate the potential trade-offs of such a modification to the engine's standard operation (a reduction in $\mathrm{CO}_{2}$ emissions being one of them).
\end{abstract}

Key words: ICE; performance; control; economy; lower emissions

\section{НАГОДУВАЊЕ НА МОТОР СВС ЗАРАДИ НАМАЛУВАЊЕ НА НЕГОВИОТ СО2-ОТПЕЧАТОК}

А п с т р а к т: Покрај негативни еколошки влијанија, дури 96,5 \% од тешките товарни возила продадени во 2020 година биле погонувани од дизел-мотор СВС, што говори дека моторите СВС уште долго ќе се задржат на патиштата. Вградувањето на каталитички конвертори и други филтерски решенија во издувните системи на возилата овозможува само делумна редукција на штетните емисии, а каква било понатамошна редукција во нивното количество подразбира компромис помеѓу моќноста на моторот и сѐ построгите еколошки стандарди. Овој труд ќе овозможи увид во работата на електронската управувачка единица (ЕУЕ) на мотор СВС, сензорите од кои прима податоци и актуаторите кои ги управува. Дополнително, во трудот го анализираме фази-логичкото управување и можностите кои ги носи менувањето на фази-логичките мапи во ЕУЕ за зголемена моќност на моторот и намалена потрошувачка на гориво. Имајќи го предвид наведеното, потпирајќи се на управувачките принципи, овој труд има за цел да ги достигне двете наведени побарувања и да ги лоцира потенцијалните компромиси во таквото нагодување и модификација на стандардното работење на моторот (како што е намалување на емисиите од $\mathrm{CO}_{2}$ ).

Клучни зборови: мотор СВС; перформанси; управување; економично возење; помало количество на емисии

\section{INTRODUCTION}

Society's need for fast and efficient transport has sped up the development of transport infrastructure, enforced laws that facilitate faster international travel and has led to the technical and technological advancement of different vehicle types. A major component of any vehicle, the internal combustion engine's (ICE) development tendency has always been directed toward greater economy, increased power output, smaller mass and longer service life. In addition, the ability not to pollute and emit greenhouse gasses are as important. Lately, both fully electric vehicles (EVs) and plug-in hybrids (PHEV) 
have been making a slow but stable entry on the passenger and light commercial vehicle market. [1]

Taking in consideration current and future legislative restrictions on exhaust tailpipe emissions, the increased presence of passenger and light commercial EVs on today's roads seems perfectly reasonable. [2,3] In spite of this, as much as $96.5 \%$ of the heavy commercial vehicles sold in 2020 were diesel driven. [1] This is a strong argument that internal combustion engines (ICEs) will stay in use for the foreseeable future. Even if there was a sudden reduction in interest and therefore sales, and the number of ICE driven vehicles dropped, ICEs would still be used in special purpose machines, in maritime use and within other vehicles that count on the robustness and power output of the diesel engine. On the other hand, this also means that most of the setbacks that come with the use of ICEs are here to stay, including their capacity to pollute [7, $8]$.

Air pollution from the transport sector and particularly from road transport [4-6] became a major environmental topic in the 1980s. Around this time, most Western-European countries, the US, Japan, and others, first limited the amount of polluting substances in exhaust emissions. With the goal to reduce air pollution and the effects of global warming, these ecological standards sought to reduce the exhaust gas opacity, and the quantity of carbon monoxide, carbon dioxide, nitrogen oxides, particulate matter, non-methane volatile organic compounds, unburned hydrocarbons etc.

Some exhaust emissions challenges that originated from the fuel's contents (petrol with lead additives and sulfur in diesels), were successfully solved with the complete ban on these additives [9], which resulted in a drastic reduction of the presence of lead and sulfur oxides in the ambient air. Air pollution from road transport today is mostly a product of the combustion process in the engine. Therefore, the problem of harmful emissions reaching the ambient air is partially solved by installing catalytic converters, filters and other solutions in the exhaust systems of the vehicles [10]. However, the possibility for a complete reduction of the harmful components lies with the optimization of the combustion process.

This emphasizes the need for new techniques and methods of tuning the combustion process in the engine and optimizing its operation according to the operating mode of the vehicle and the needs of the driver. Fuzzy-logic control and the process of altering the fuzzy-logic maps in the vehicle's electronic control unit (ECU) offer tempting opportunities for increased engine power output and better fuel economy. [11-14] With this in mind, the aim of this paper is to analyze the principles of fuzzy-logic control of the ICE, to try to achieve both of these requirements and understand the potential advantages and disadvantages in terms of exhaust emissions of such a modification in the operation of the engine.

\section{MATERIALS - ENGINE CONTROL UNIT (ECU)}

With an increased development in technology, computer control systems, which were usually found in larger scale industrial systems, are now increasingly found in commercial products for everyday use. The automotive industry consistently follows both the technical and technological evolution and contributes with numerous innovations to the development trends. A great example is the "control era' of automotive technology that started in the $90 \mathrm{~s}$ and aims to simplify the use of cars. Understandably, this offers numerous benefits for the user, but also for the environment. Some of these benefits are greater vehicle safety and reliability, an increase in the engine power output, reduced fuel consumption and a significant reduction in the amount of harmful exhaust emissions. This is achieved with the help of numerous sensors and actuators controlled by the ECU of the vehicle, along with precise control logic that processes data at high speed, and which does not require large resources.

Engine control is pretty complex as it involves strict exhaust emission criteria and reduced fuel consumption, with no loss of engine performance. For this purpose, the ECU must quickly process inputs from engine and vehicle sensors and adjust the position of different actuators as an output, thereby meeting the needs of the driver and the required power delivered by the engine. At the same time, this process must meet the set ecological norms and achieve all of the above with optimal fuel consumption.

Considering that passenger and light commercial vehicles in the EU are 11.5 and 11.6 years old, respectively [15], or otherwise at the transition from EURO 4 to EURO 5 emission standard, the vehicle we used for our research is a SEAT Leon Mk II 1.9 TDI, manufactured in 2009, in accordance with the EURO 4 standard. This vehicle has a BOSCH EDC 16 control module with a Motorola MPC 564 (Figure 1) microcontroller, manufactured in 2001. 


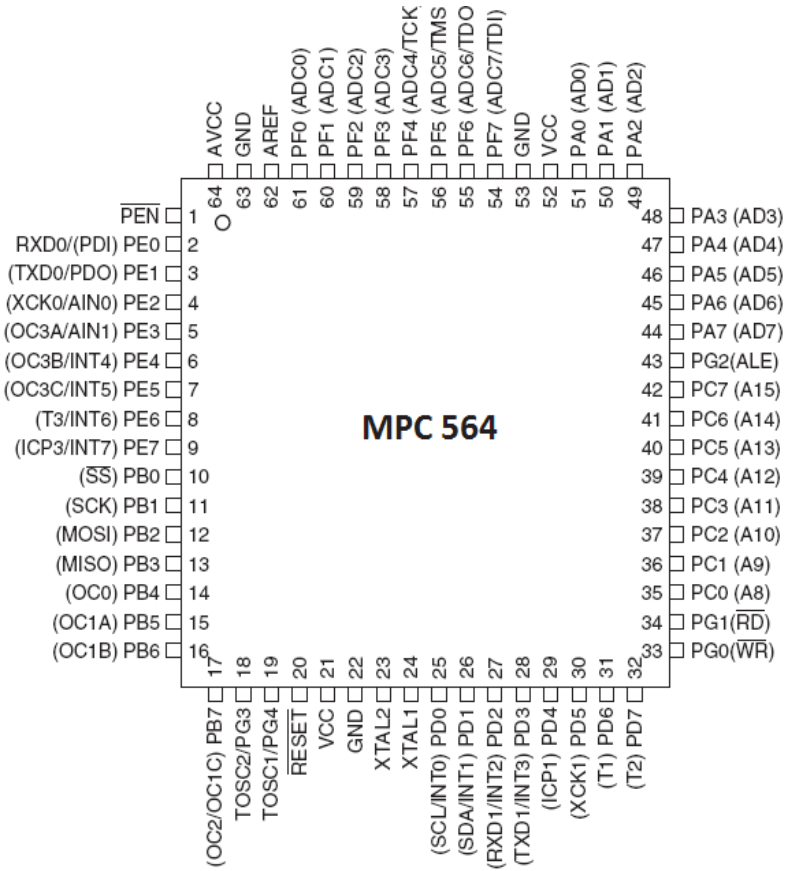

Fig. 1. Motorola MPC 564 microcontroller housing pin layout

The ECU receives information from the engine sensors through multiple analogue and digital inputs, and sends commands to the motor control actuators through digital outputs. Due to its performance, temperature operating range and shock resistance, this ECU is widely used in the automotive industry.

The ECU receives input data from: accelerator pedal position sensor (APPS), the camshaft position sensor, the crankshaft position sensor, the transmission position sensor, the engine coolant temperature sensors mounted on the engine block and radiator, the fuel temperature sensor (FTS), the intake air temperature sensor (IAT), the mass airflow sensor (MAF), and the turbocharger (boost) pressure sensor.

Actuators controlled by the ECU are: the electric fuel pump, the exhaust gas recirculation (EGR) solenoid valve, the recirculating exhaust gas cooling valve, the fuel heaters module, fuel injectors, solenoid airflow control valve, and a compressor bypass valve (CBV).

\section{METHODS - FUZZY-LOGIC CONTROL}

The duration of the engine control cycle must be very short, and linear control (such as PID control) has been found less suited for this purpose. However, fuzzy-logic control offers a more convenient control logic without the need for large hardware requirements, while the time of the engine control cycle is reduced to a minimum.

In the past, controller manufacturers used lookup tables that represented control logic, which they obtained through a lot of testing or using the "trial-and-error" method and accumulated experience through the lessons learned (one of the guiding principles of fuzzy-logic control). The main disadvantage of lookup tables-based control is that they take up a lot of memory and it takes the ECU a significant amount of time to select an appropriate table in response to the driver's requirements, and the vehicle's operating conditions. As a result, car manufacturers today base their ECUs on fuzzy-logic and convert the fuzzy-control system output into lookup tables, or fuzzy-logic maps.

The ECU's memory holds more than 200 control maps, meaning that for the same output we can have more maps, i.e. more outputs managing the same actuator. We also have fuzzy-logic control when the ECU is monitoring the engine condition, making conclusions based on engine data which determines which map is most suitable for the current control requirements of the engine.

The main advantages of this type of control are the fast reaction time of the controller, a control cycle only takes a very small amount of time, there is virtually no need for expensive hardware (processor, RAM and similar components) and there is an easy access to the engine control parameters for further optimization. Perhaps the only drawback is the need for a large ROM to store all the maps, but as an alternative, an external EEPROM (electrically erasable programable read-only memory) is used within the ECU. Given the fact that the cost of semiconductor components used for this type of memory is quite low, and this way the control speed is increased several times over, this method of control is entirely financially justified.

\section{RESULTS}

The fuzzy-logic maps used as lookup tables within the ECU are obtained as outputs from a fuzzy controller and hold predetermined values that the engine should achieve, namely power ( $\mathrm{kW}$ or $\mathrm{hp}$ ), torque $(\mathrm{Nm})$ and the amount of pollutants in the exhaust emissions, expressed as a percentage (\%) of the volume of total exhaust emissions.

All of the maps are located in a hex file (HEX - hexadecimal source file) within the ECU's EEPROM, but to get them to the desired state 
requires hard work and many precise calculations (as a safety measure that protects the manufacturer from amateurs damaging the engine and causing expensive and often irreversible defects). Using mathematics, experience and experimentation, we can fine-tune some of the operating parameters, in order to get greater performance from the vehicle and reduced fuel consumption. In order to perform this engine optimization, we will have to change more than 50 maps, but in the interest of the available space in this paper, Appendix 1 presents only some of them. The maps are displayed so that the coefficients changed (relative to the factory condition) are highlighted in red.

First, we will take a look at the dynamometer results for the power output, per the factory settings of the vehicle (without any optimization) which we will take as reference value (Figure 2a). We can see that by default the car has a maximum power output of $78 \mathrm{~kW}$ or $106 \mathrm{hp}$ (reached at $4000 \mathrm{rpm}$ ) or a maximum torque of $250 \mathrm{Nm}$ (reached at $2300 \mathrm{rpm}$ ).

However, by looking at Figure 2b, which shows the power output curve after we performed the "Performance" optimization, we notice that the same engine is now able to reach a maximum power output of $106 \mathrm{~kW}$ or $144 \mathrm{hp}$ (achieved at $3277 \mathrm{rpm}$ ), i.e. a maximum torque of $324.8 \mathrm{Nm}$ (achieved at $2971 \mathrm{rpm})$.
We should note, that while we increased the power output, we are still left with room to make the engine more efficient in terms of its fuel consumption. The fuel consumption measured by the vehicle's on-board computer after passing $100 \mathrm{~km}$ with combined driving (both urban and on the highway) before the optimization was $6.61 / 100 \mathrm{~km}$ (Figure 3a). After performing the "Performance" optimization, the fuel consumption measured by the car's onboard computer after $100 \mathrm{~km}$ with combined drive is exactly $61 / 100 \mathrm{~km}$ (Figure 3b).

Finally, we measured the quantity of the different components found in the vehicle's exhaust emissions that fall under the legal frameworks of the Republic of North Macedonia and in particular the Rulebook for the technical inspection of vehicles [18] in the Republic of North Macedonia. As we can see by comparing Figures $4 a$ and $4 b$, the major difference between the non-optimized engine and the same engine following the "Performance" optimization is in the reduced $\mathrm{CO}_{2}$ emissions. Prior to the optimization the engine emits $3.43 \% \mathrm{CO}_{2}$ per volume of exhaust emissions, while after the optimization, the engine emits $2.30 \% \mathrm{CO}_{2}$ per volume of exhaust emissions. The optimized engine also shows an increase in its $\mathrm{CO}_{2}$ emissions.

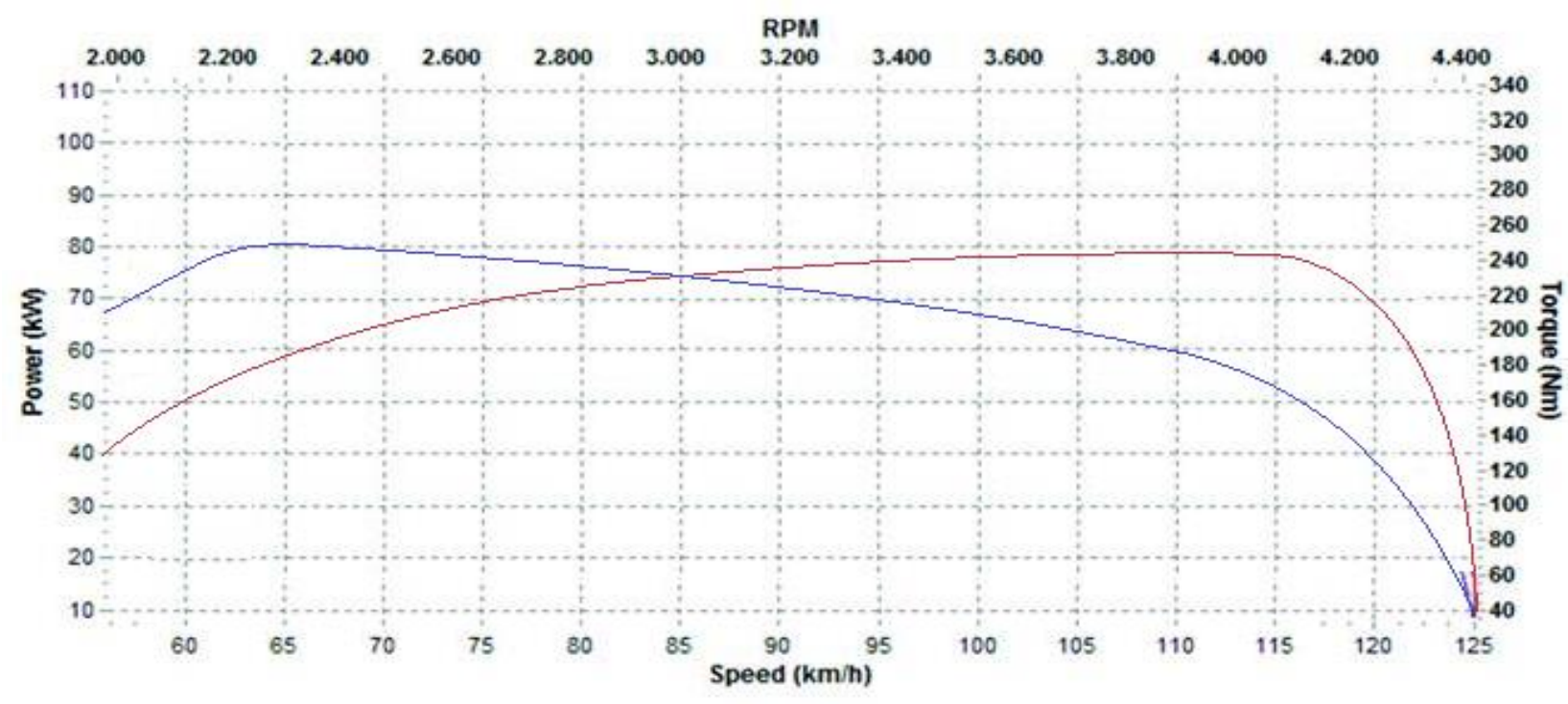

Max engine power (measured) :

Max engine power (corrected) :

Loss power on transmission :

Max engine torque (measured) :

Max engine torque (corrected) :

Max wheel power (corrected) :

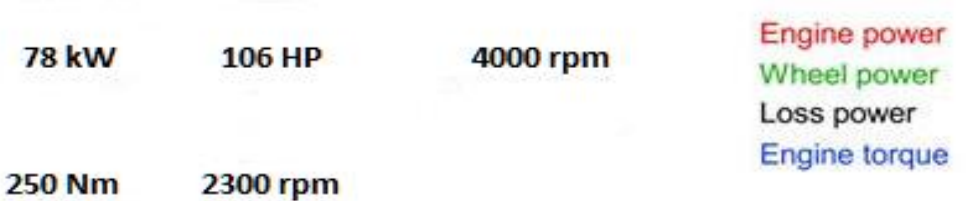

$250 \mathrm{Nm} \quad 2300 \mathrm{rpm}$

Fig. 2a. Power output of the non-optimized SEAT Leon engine 


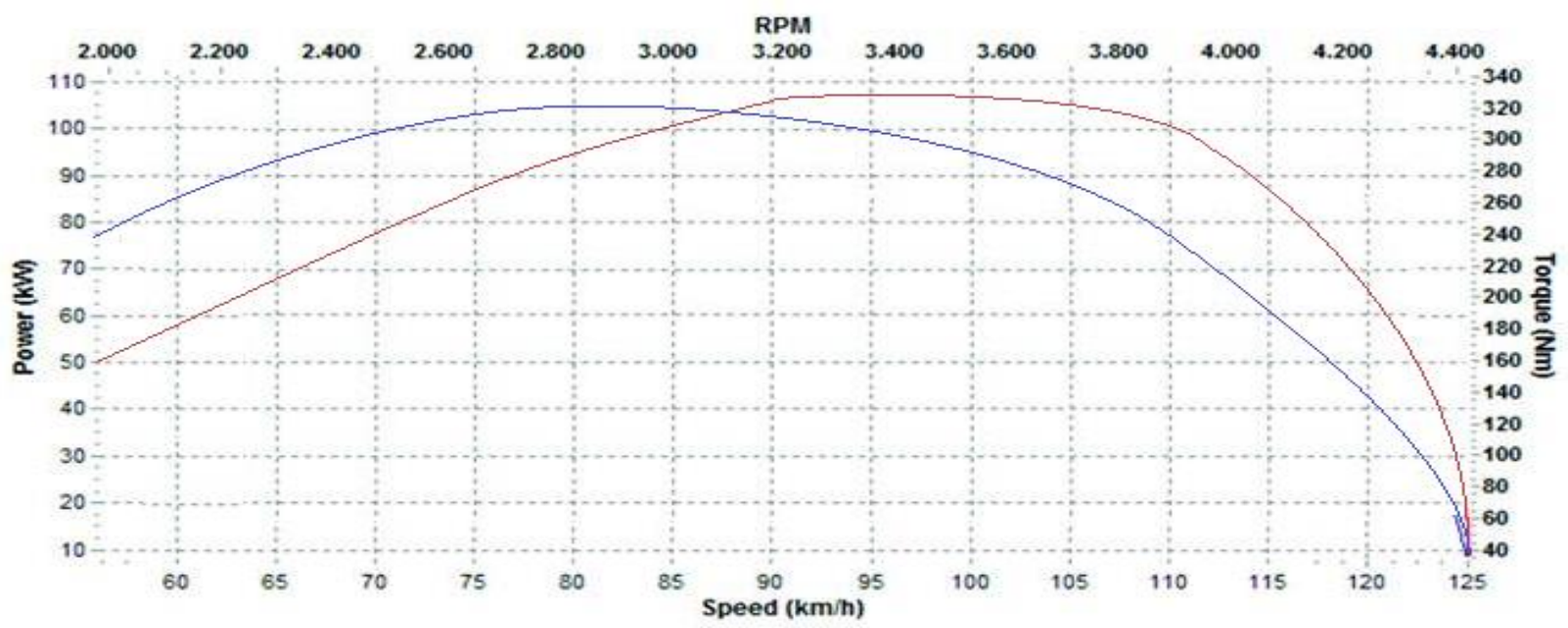

Max engine power (measured) :

Max engine power (corrected) :

106 kW

144 HP

$324,8 \mathrm{Nm}$
( $3277 \mathrm{rpm}$ )

$(124,3 \mathrm{~km} / \mathrm{h}$ )

2971 rpm
Engine power

Wheel power

Loss power

Engine torque

Max engine torque (measured) :

Max engine torque (corrected)

Max wheel power (corrected)

Fig. 2b. Power output for a "Performance" optimization of the SEAT Leon engine

\section{ø $1 / 100 \mathrm{~km}$ $\square$}

a)

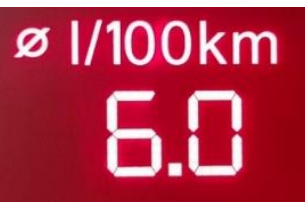

b)

Fig. 3. Fuel consumption of the:

a) non-optimized SEAT Leon engine, b) "Performance" optimization of the SEAT Leon engine

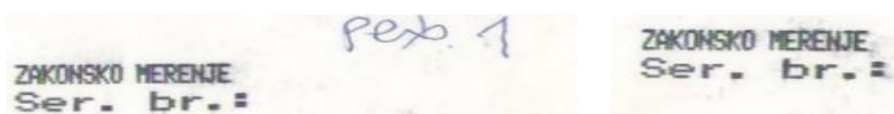

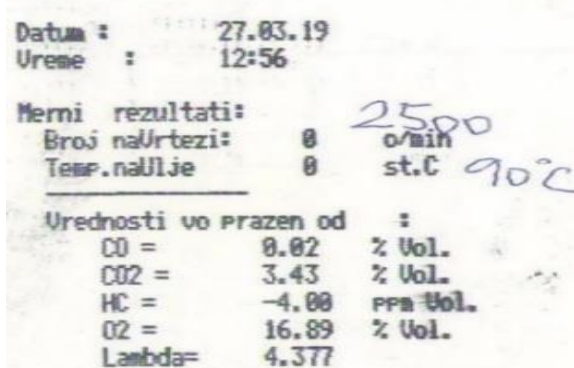

Kontrolor:

a)

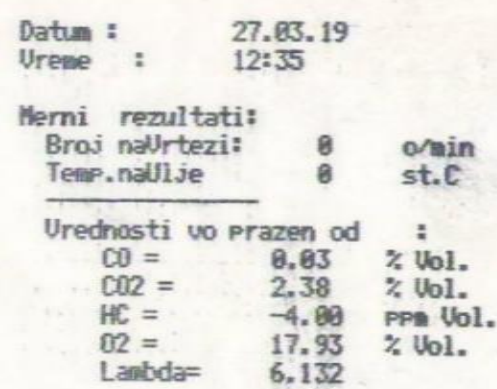

Kontrolor:

b)

Fig. 4. Results for the exhaust emissions of the:

a) non-optimized SEAT Leon engine, b) "Performance" optimization of the SEAT Leon engine 


\section{DISCUSSION}

It is perfectly reasonable to wonder why the manufacturer would not do these optimizations when clearly, the engine is designed to have a higher power output. The answer lies with taking account of the market/s where the particular vehicle is being sold. Therefore, the fuzzy-logic control maps chosen, reflect specific legal norms, such as ecology standards, traffic safety norms, conditions for the technical approval of vehicles, taxation conditions, etc., in the countries that make the biggest part of the vehicle market. The most attention is paid to the environmental norms, because they are very easily controlled at the annual technical inspection of the vehicle, by measuring the exhaust emission.

In the case of this paper and the vehicle tested, the engine will maintain most of the required environmental norms. Only after long-term operation of the vehicle would it be possible to reduce the ecological norms, however within the limits predicted by the manufacturer due to wear of the engine components. Our test vehicle will meet the emission standards in the EURO 4 standard, but the reduction in fuel consumption and increase in power will affect the amount of nitrogen oxides and particulate matter in the exhaust emissions. Even then, the ecological norms (according to the performed measurements) will not drop in the EURO 3 standard.

\section{CONCLUSION}

Thanks to the research done in preparation for this paper, which refers to the improvement of engine performance and reduction of fuel consumption in ICEs, we can state that there is no optimal engine cycle, but a compromise should be made in the design of the ICE from the point of energy efficiency and maximum utilization of the energy released by the fuel.

Using modern and advanced control systems we can achieve a more optimal combustion process within the ICE, in which the ratio of the energy released from the combustion of fuel and the combustion products would be more ideal. Utilizing the processing power and complex control algorithms of the engine's ECU, along with the engine's sensor and actuator elements, and a feedback loop that allows the ECU to monitor the momentary state of the combustion process, the engine's performance is controlled at a speed of several thousand reactions per second. Seeing as different environmental conditions and operating modes of the vehicle require specific adjustment of the engine's working parameters, we can further optimize these algorithms in order to increase the engine and therefore the vehicle's power output and improve its fuel economy. Thanks to the reduced fuel consumption, we will also have reduced the vehicle's $\mathrm{CO}_{2}$ emissions, but at the cost of increasing the amount of nitrogen oxides and solid particles.

The aforementioned the second (delayed fuel injection) and third (duration of the fuel injection) modifications offer different benefits but come with their own disadvantages. Nevertheless, they make perfect points for further research, whose results would be detrimental in determining which optimization of the operating parameters is the most appropriate for a specific operating mode of the vehicle. Furthermore, by increasing the number of combinations between the fuzzy-logic maps and then storing them as separate files in the ECU's EEPROM we could allow the driver to select the most appropriate driving mode (urban, highway, etc.) or by applying the principles of machine learning we can have an autonomous selection of the most appropriate map package.

\section{REFERENCES}

[1] ACEA: Fuel Types of New Trucks. European Automobile Manufacturers Association (2020). Available at: https:// www.acea.auto/fuel-cv/fuel-types-of-new-trucks-diesel-9 6-5-electric-0-4-alternative-fuels-2-9-market-share-in-20 $20 /$

[2] Preston, B.: EVs Offer Big Savings Over Traditional GasPowered Cars. Consumer Reports (2020). Available at: https://www.consumerreports.org/hybrids-evs/evs-offerbig-savings-over-traditional-gas-powered-cars/

[3] EERE: Reducing Pollution with Electric Vehicles. Office of Energy Efficiency \& Renewable Energy (2020). Available at: https://www.energy.gov/eere/electricvehicles/reducing-pollution-electric-vehicles

[4] Delasalle, F., Erdenesanaa, D.: Planes, Trains and (Big) Automobiles: How Heavy Transport Can Reduce Emissions and Save Money, 2019. World Resources Institute. Available at: https://www.wri.org/blog/2019/07/planes-tra ins-and-big-automobiles-how-heavy-transport-can-reduce -emissions-and-save

[5] Teixeira, P. R., De Freitas, S. R., Correia, F. W., Manzi, A. O.: MOVEIM v1.0: Development of a bottom-up motor vehicular emission inventories for the urban area of manaus in central Amazon rainforest. Geoscientific Model Development 1-21 (2018).

[6] Hooftman, N.: A review of the European passenger car regulations - Real driving emissions vs local air quality. Renewable Sustainable Energy Rev. 86 (2018).

[7] Michalek, J. J., Chester, M., Jaramillo, P., Samaras C., Shiau, C-S. N., Lave L. B.: Valuation of plug-in vehicle life-cycle air emissions and oil displacement benefits. Proceedings of the National Academy of Sciences of the 
United States of America. PNAS October 4, 2011, 108 (40) 16554-16558. https://doi.org/10.1073/pn as.1104 473108

[8] Tessum, C. W., Hill, J. D., Marshall, J. D.: Life cycle air quality impacts of conventional and alternative light-duty transportation in the United States. Proceedings of the National Academy of Sciences of the United States of America. PNAS December 30, 2014, 111 (52) 1849018495; first published December 15, 2014. https://doi.org /10.1073/pnas.1406853111

[9] EU: Directive 98/70/EC of the European Parliament and of the Council of 13 October 1998 relating to the quality of petrol and diesel fuels and amending Council Directive 93/12/EEC. Official Journal L 350, 28/12/1998, pp. 0058 - 0068 (1998). Available at:

http://publications.europa.eu/resource/cellar/9cdbfc9b-d8 14-4e9e-b05d-49dbb7c97ba1.0 008.01/DOC_1

[10] Giakoumis, E.: Diesel and spark ignition engines emissions and after-treatment control: Research and Advancements. Energies, 10 (11), 1882 (2017). https://doi.org/10.33 90/en10111882

[11] Nekooei, M., Koto. J.: A simple fuzzy-logic diagnosis system for control of internal combustion engines. Jurnal Teknologi. 74 (5), pp. 121-124 (2015).

DOI: $10.11113 /$ jt.v74.4652

[12] Simani, S., Bonfè, M.: Fuzzy modelling and control of the air system of a diesel engine. Advances in Fuzzy Systems.
Volume 2009 |Article ID 450259. https://doi.org/ 10.1155/2009/450259

[13] Wong, P. K., Tam, L. M., Li, K.: Automotive engine power performance tuning under numerical and nominal data. Control Engineering Practice. 20 (3), pp. 300-314 (2012). DOI:10.1016/j.conengprac.2011.11.006.

[14] Singh, J., Perisamy, C.: Innovation in cohesive stock ECU Tuning And Turbocharging (2009). International Journal of Innovative Technology and Research. 4. pp. 5252-5255 (2016).

[15[ ACEA: Average age of the EU vehicle fleet, by country. European Automobile Manufacturers Association (2021) Available at: https://www.acea.auto/figure/ average-ageof-eu-vehicle-fleet-by-country/

[16] Tutak,W., Jamrozik, A., Bereczky A.: Effects of injection timing of diesel fuel on performance and emission of dual fuel diesel engine powered by diesel/E85 fuels. Transport. 33. pp. 633-646 (2018). DOI:10.3846/transport.2018.157 2

[17] Ahmed, S. A., Zhou, S., Zhu, Y., Feng, Y., Malik, A., Ahmad, N.: Article influence of injection timing on performance and exhaust emission of CI engine fuelled with butanol-diesel using a 1D GT-power model. Processe. 7 (5), 299 (2019). https://doi.org/10.3390/pr7050299

[18] Ministry of Interior: Rulebook for the technical inspection of vehicles. Official Gazette of the Republic of North Macedonia. Number 81/2010 (in Macedonian). 


\section{APPENDIX}

Modified fuzzy-logic maps for the optimization of the working parameters of an ICE

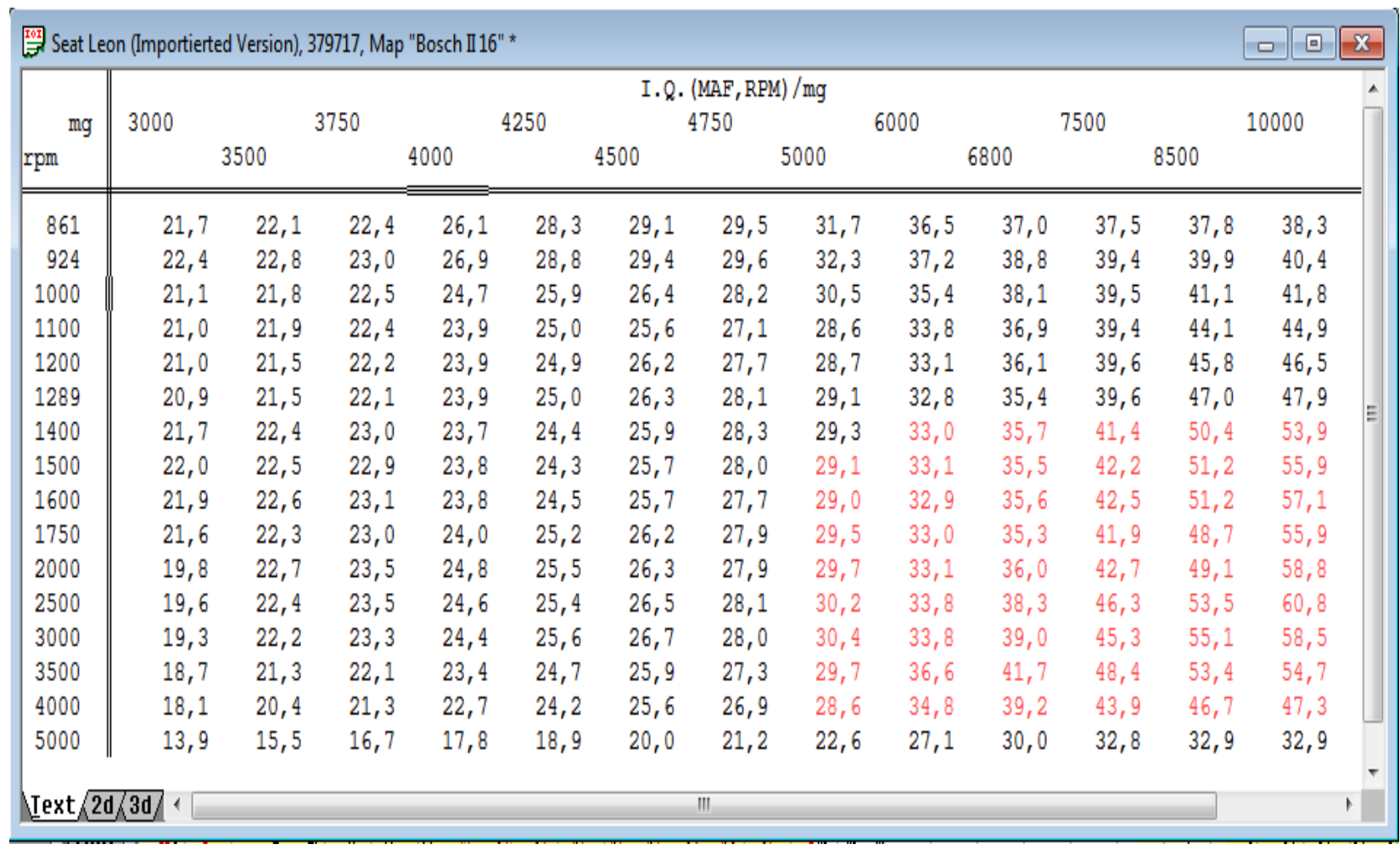

Fig. 1. Modified fuzzy-logic map controlling the quantity of fuel dependent on the fresh air intake

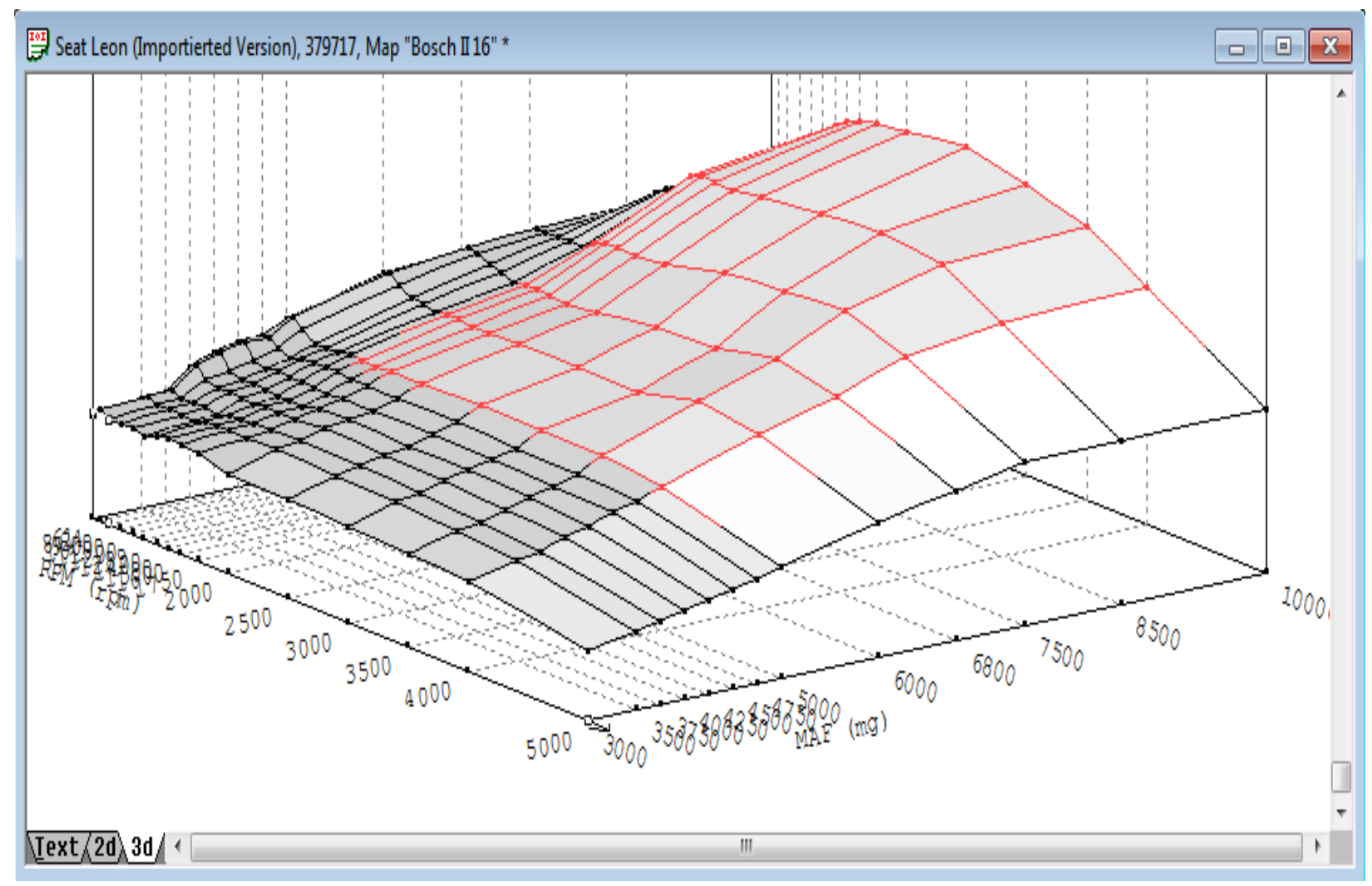

Fig. 2. Modified control surface for the control of the quantity of fuel dependent on the fresh air intake 


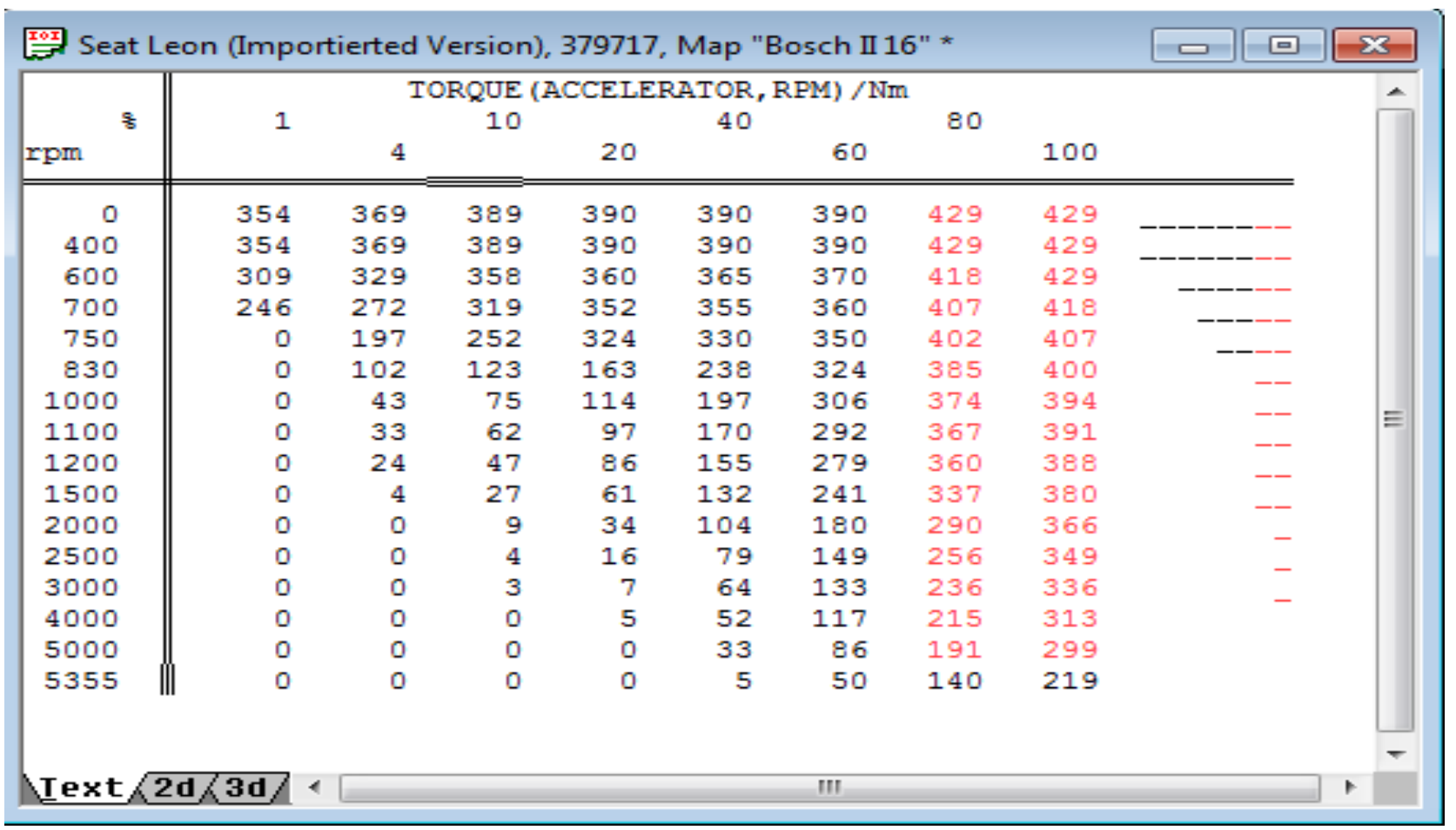

Fig. 3. Modified fuzzy-logic-map for the accelerator pedal position

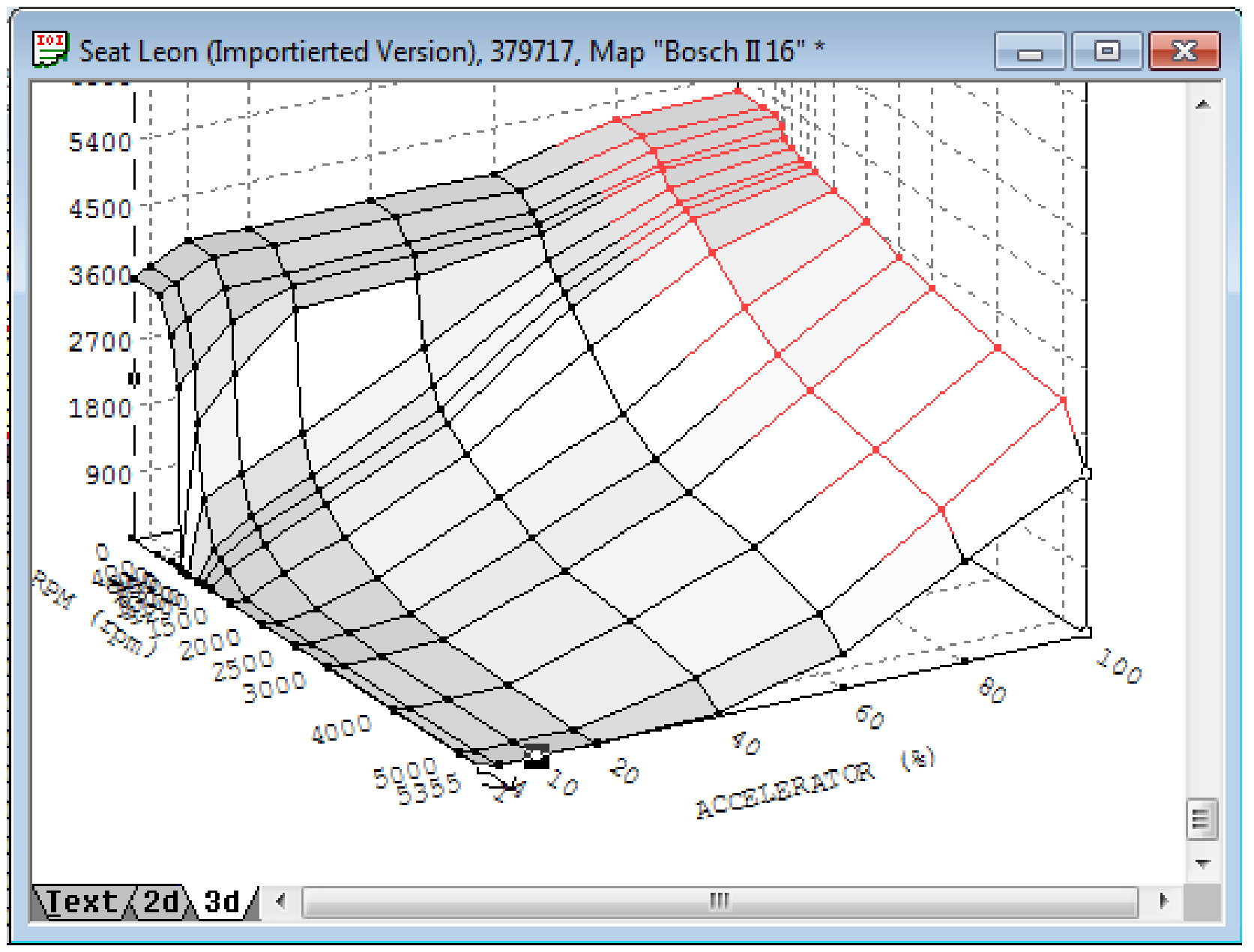

Fig. 4. Modified control surface for the accelerator pedal position 


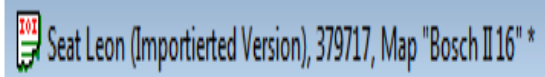

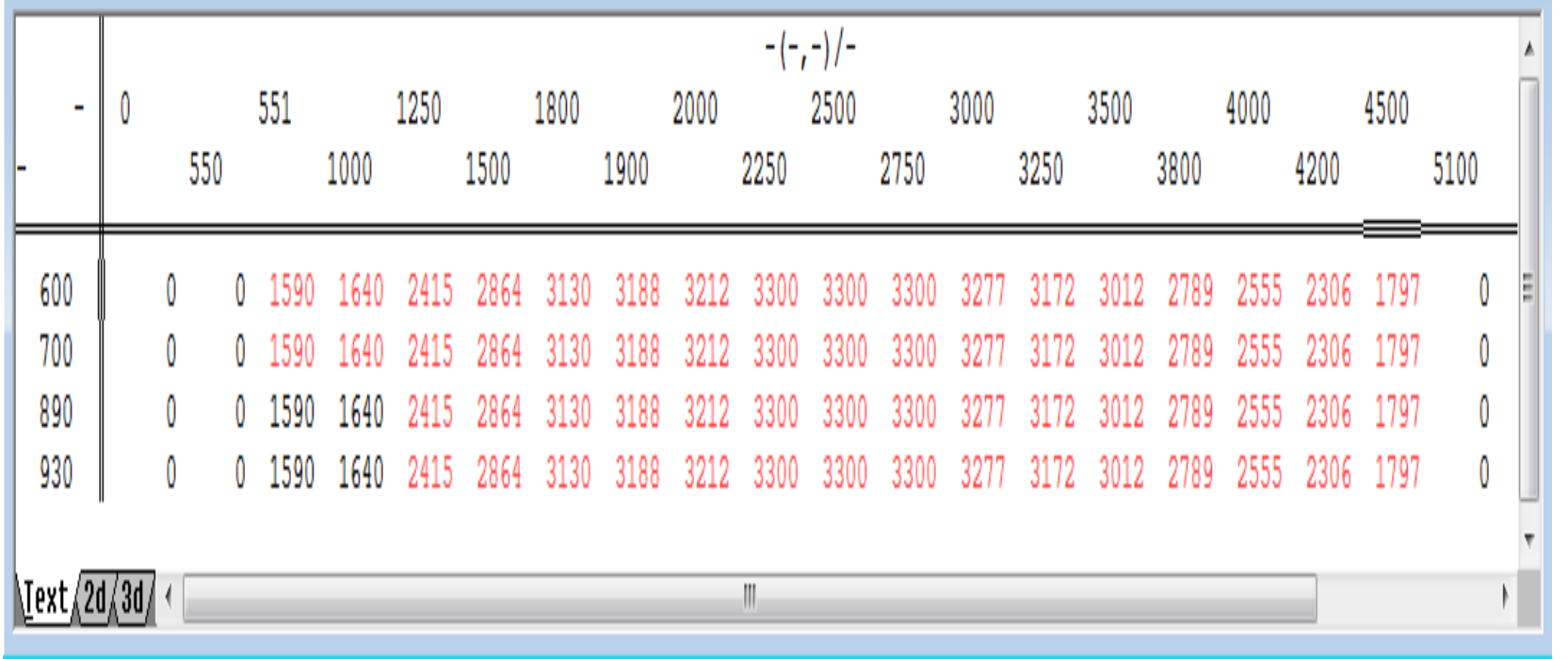

Fig. 5. Modified fuzzy-logic map to limit the torque

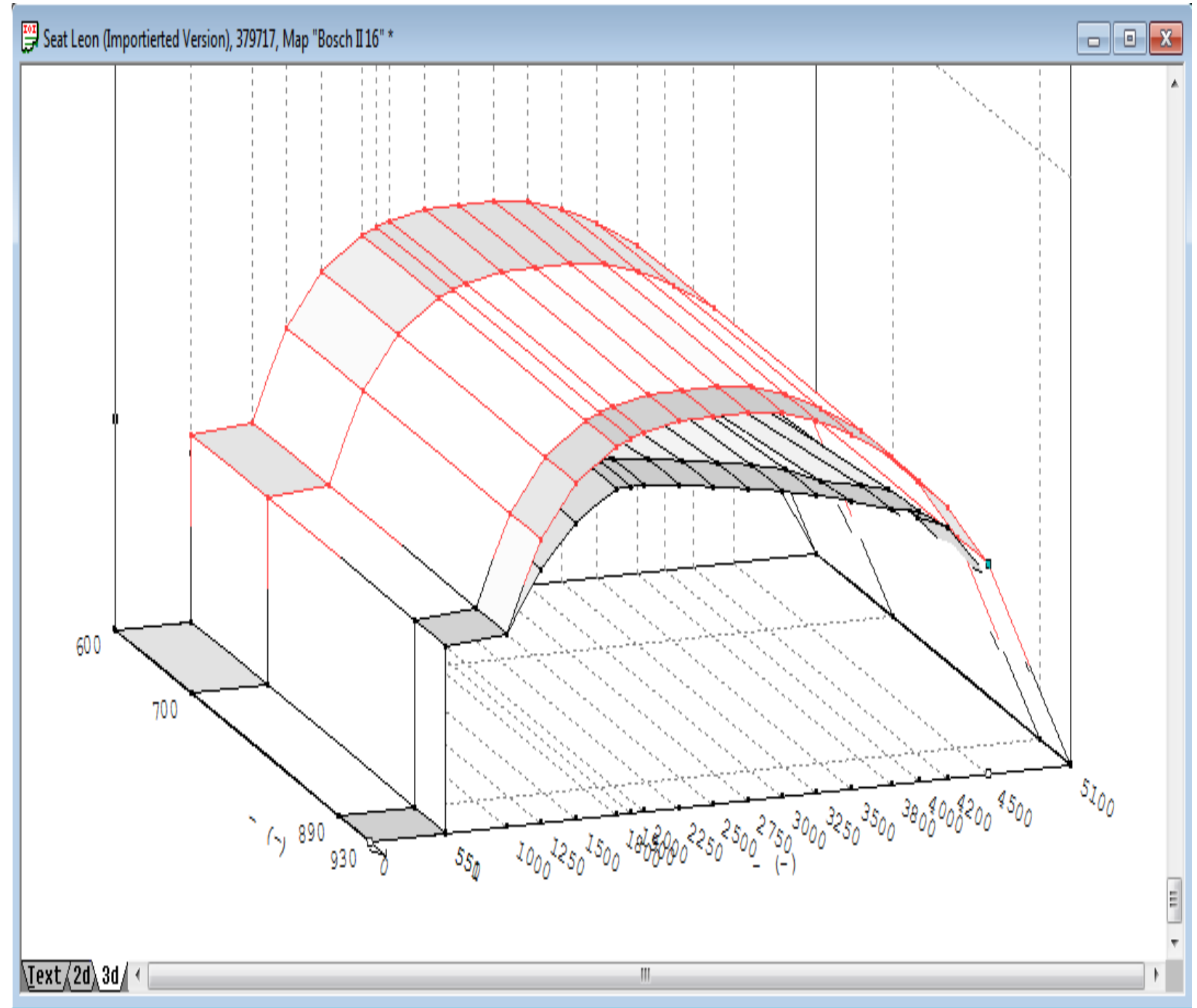

Fig. 6. Modified control surface to limit the torque 


\begin{tabular}{|c|c|c|c|c|c|c|c|c|c|c|c|c|c|c|c|c|}
\hline \multicolumn{16}{|c|}{ 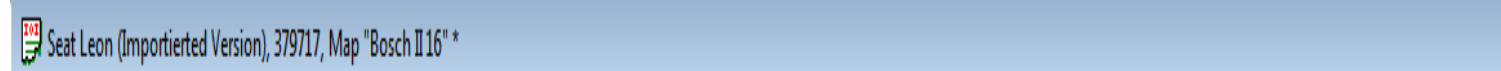 } & \multirow{2}{*}{ 묘 } \\
\hline \multirow{3}{*}{$\mathrm{rgm}$} & \multicolumn{15}{|c|}{ Conversion table (Morgue, RPM)/mg } & \\
\hline & 0 & 50 & & & 94 & & 138 & & 182 & & 226 & & \multirow[t]{2}{*}{270} & \multirow{2}{*}{\multicolumn{2}{|c|}{314}} & \multirow[b]{2}{*}{336} \\
\hline & \multicolumn{2}{|c|}{28} & \multicolumn{2}{|c|}{72} & \multicolumn{2}{|c|}{116} & \multicolumn{2}{|c|}{160} & \multicolumn{2}{|c|}{204} & \multicolumn{2}{|c|}{248} & & & & \\
\hline 1000 & 0,00 & 3,90 & 7,37 & 11,05 & 14,67 & 18,47 & 25,05 & 27,30 & 35,26 & 41,26 & 44,10 & 49,45 & 54,94 & 60,58 & 66,54 & 72,40 \\
\hline 1250 & 0,00 & 3,79 & 7,10 & 10,83 & 14,51 & 18,31 & 22,30 & 26,12 & 29,68 & 32,50 & 39,80 & 45,61 & 46,64 & 51,48 & 56,45 & 61,97 \\
\hline 1500 & 0,00 & 3,85 & 7,27 & 11,60 & 14,82 & 18,51 & 21,86 & 25,99 & 29,45 & 32,93 & 35,24 & 40,00 & 44,92 & 48,92 & 54,17 & 59,57 \\
\hline 1750 & 0,00 & 3,89 & 7,32 & 11,02 & 15,13 & 18,33 & 21,89 & 25,92 & 29,56 & 33,05 & 35,20 & 38,33 & 42,75 & 48,11 & 52,61 & 59,03 \\
\hline 2000 & 0,00 & 3,84 & 7,18 & 10,98 & 15,23 & 18,29 & 21,92 & 25,76 & 29,64 & 32,97 & 34,30 & 38,16 & 41,70 & 47,04 & 51,86 & 58,02 \\
\hline 2250 & 0,00 & 3,78 & 7,02 & 10,67 & 15,00 & 18,38 & 21,97 & 25,63 & 29,27 & 33,31 & 34,18 & 37,89 & 41,54 & 47,05 & 51,73 & 58,80 \\
\hline 2500 & 0,00 & 3,66 & 6,82 & 10,47 & 14,87 & 18,20 & 21,92 & 25,54 & 29,08 & 32,56 & 34,73 & 37,76 & 42,00 & 45,89 & 50,94 & 60,80 \\
\hline 2750 & 0,00 & 3,62 & 6,69 & 9,98 & 13,91 & 17,85 & 21,57 & 24,73 & 28,24 & 31,84 & 34,64 & 37,90 & 42,45 & 46,60 & 51,20 & 60,85 \\
\hline 3000 & 0,00 & 3,60 & 6,69 & 9,90 & 13,50 & 16,85 & 20,44 & 24,04 & 27,63 & 31,38 & 35,02 & 38,80 & 42,86 & 47,13 & 51,66 & 60,89 \\
\hline 3250 & 0,00 & 3,60 & 6,66 & 9,88 & 13,40 & 16,63 & 20,05 & 23,54 & 27,18 & 31,05 & 35,19 & 42,03 & 45,42 & 50,46 & 55,33 & 60,95 \\
\hline 3500 & 0,00 & 3,62 & 6,72 & 9,87 & 13,34 & 16,68 & 20,21 & 23,76 & 27,44 & 31,57 & 36,10 & 42,52 & 46,31 & 51,04 & 55,97 & 61,10 \\
\hline 4000 & 0,00 & 3,57 & 6,55 & 10,04 & 13,43 & 16,72 & 20,21 & 24,01 & 27,60 & 32,82 & 37,24 & 43,59 & 47,21 & 52,05 & 57,11 & 62,62 \\
\hline 4200 & 0,00 & 3,61 & 6,67 & 10,12 & 13,48 & 16,84 & 20,31 & 24,13 & 29,36 & 34,00 & 37,74 & 45,58 & 47,81 & 52,73 & 57,87 & 63,47 \\
\hline 4500 & 0,00 & 3,68 & 6,84 & 10,23 & 13,55 & 17,01 & 20,47 & 25,08 & 29,66 & 34,30 & 38,32 & 43,99 & 48,71 & 53,75 & 59,01 & 64,75 \\
\hline 5000 & 0,00 & 3,76 & 6,99 & 10,38 & 13,78 & 17,29 & 20,81 & 24,79 & 29,27 & 33,61 & 38,47 & 43,19 & 48,07 & 53,09 & 58,33 & 64,10 \\
\hline
\end{tabular}

Fig. 7. Modified fuzzy-logic map for torque converted in quantity of fuel

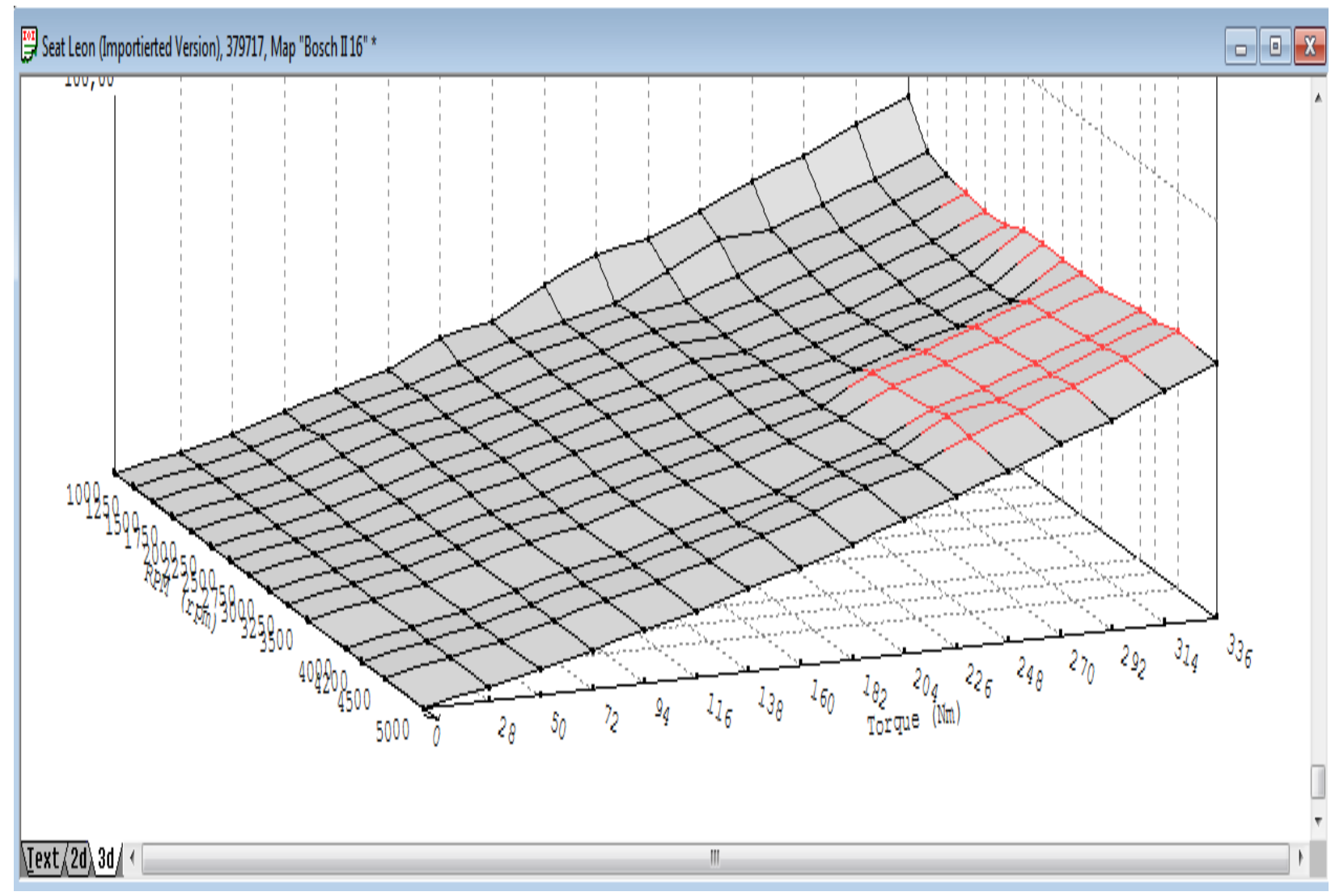

Fig. 8. Modified control surface for torque converted in quantity of fuel 


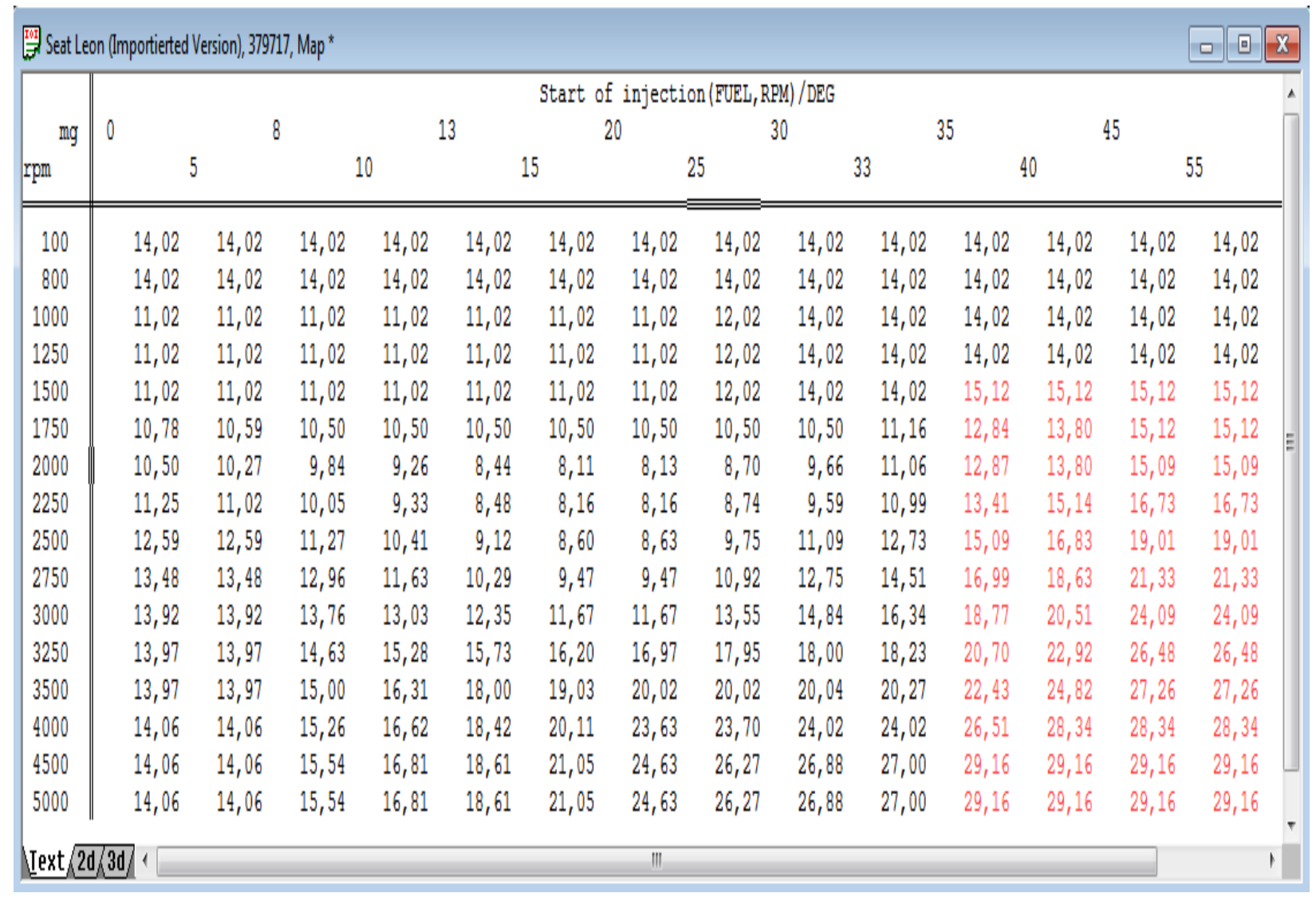

Fig. 9. Modified fuzzy-logic map for the moment of fuel injection

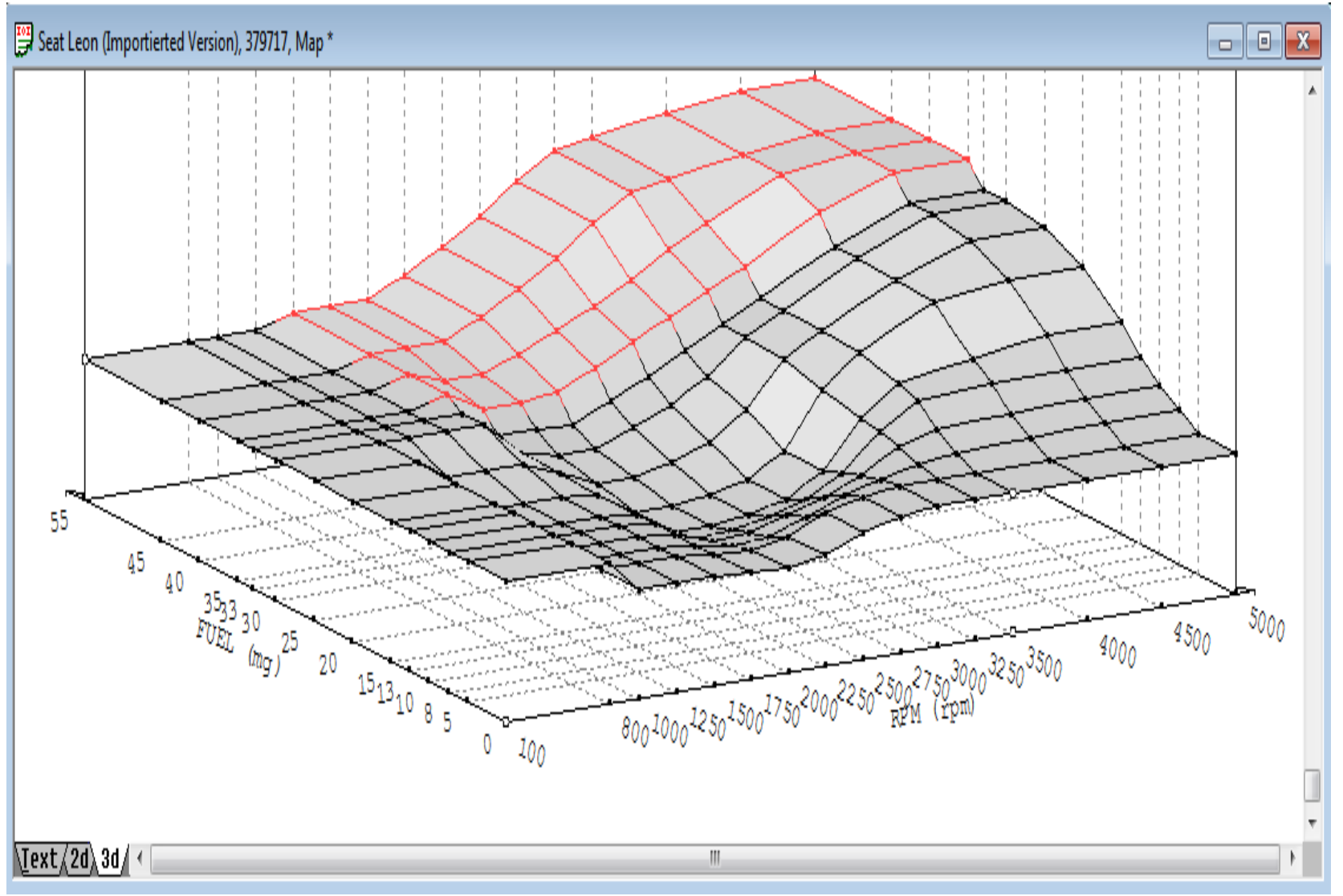

Fig. 10. Modified control surface for the moment of fuel injection 


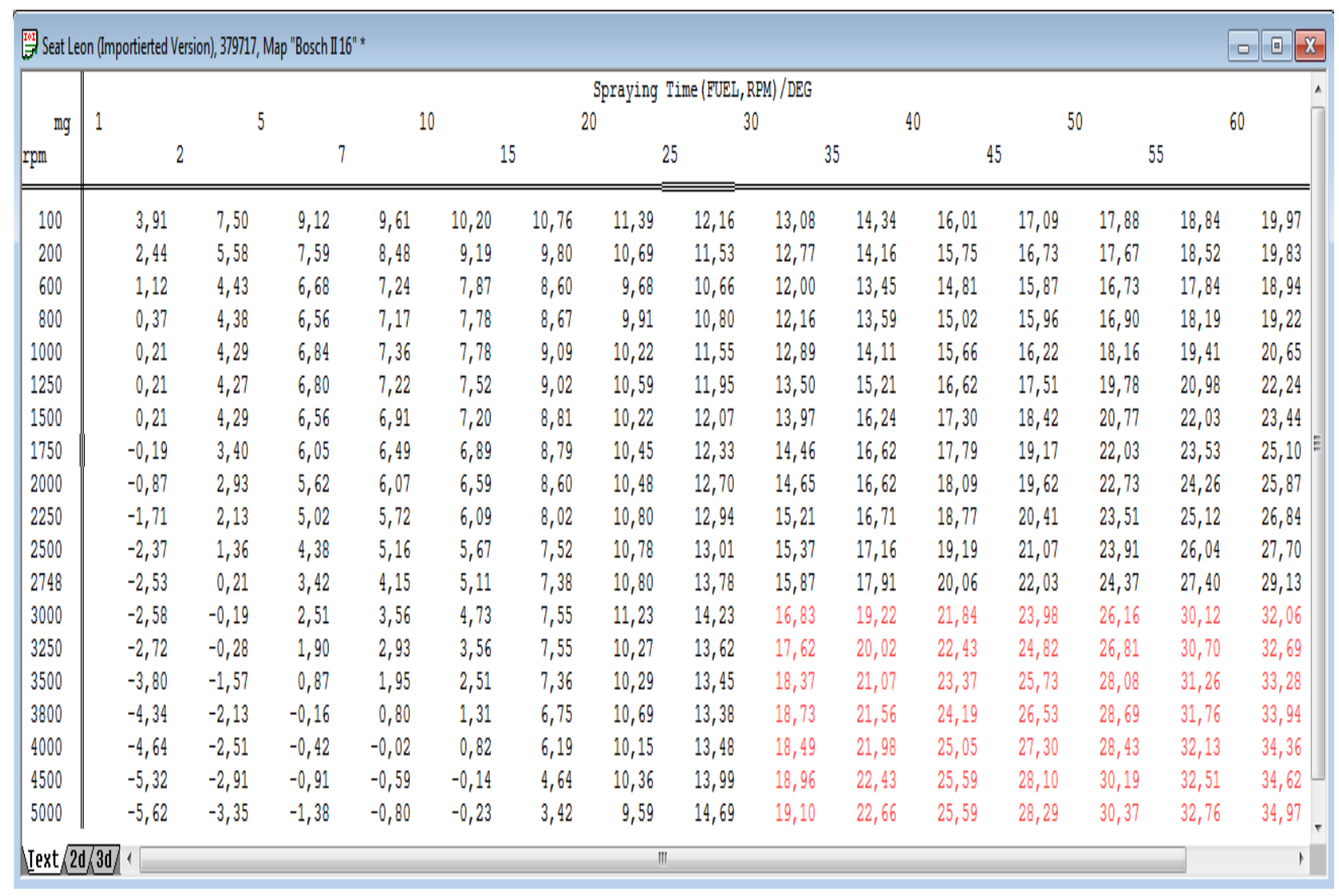

Fig. 11. Modified fuzzy-logic map for the quanitity of injected fuel

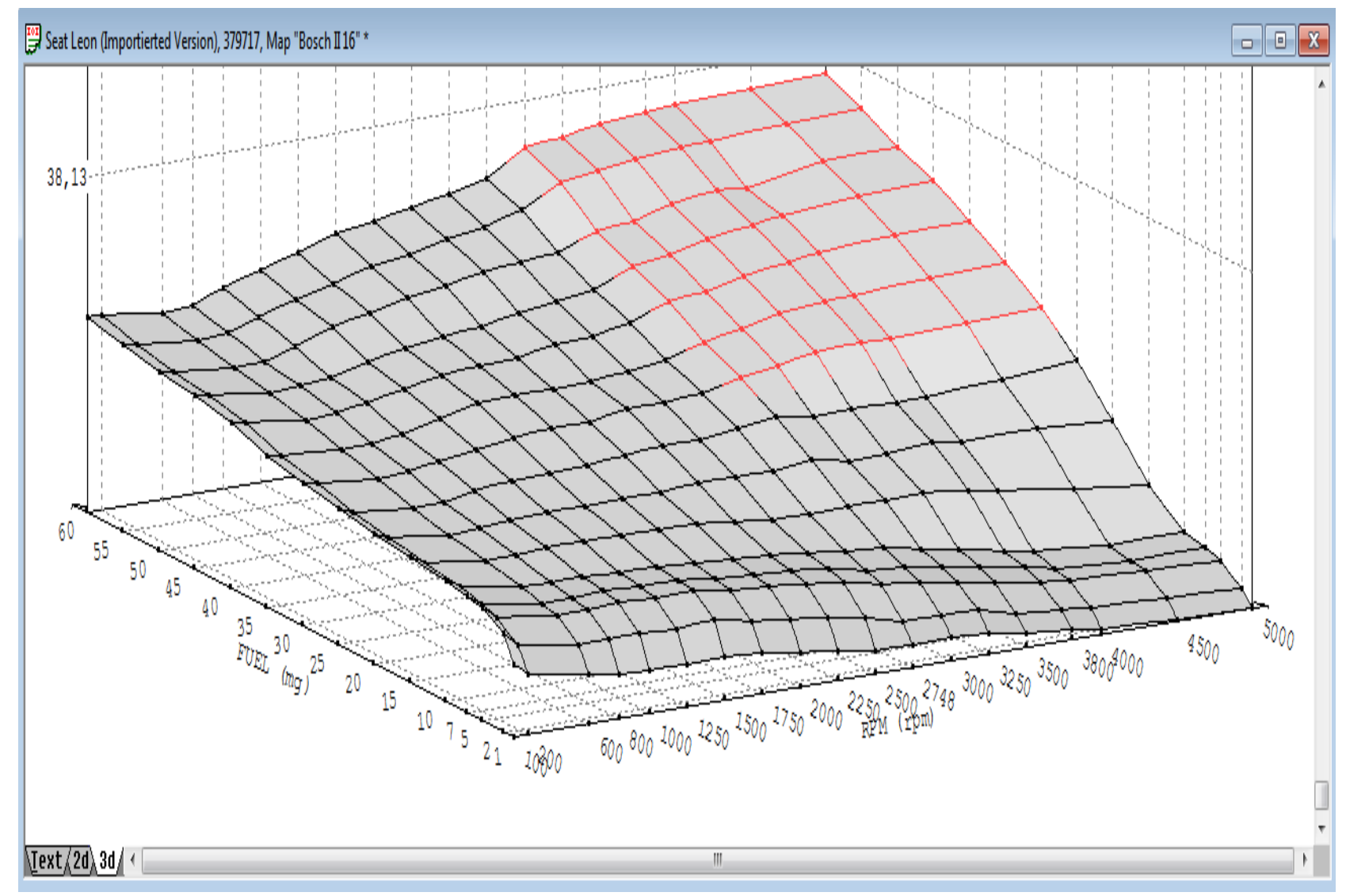

Fig. 12. Modified control surface for quantity of injected fuel 


\begin{tabular}{|c|c|c|c|c|c|c|c|c|c|c|c|c|}
\hline \multicolumn{11}{|c|}{ Seat Leon (Importierted Version), 379717, Map "Bosch II 16" * } & \multicolumn{2}{|c|}{\begin{tabular}{|l|l} 
& 0 \\
&
\end{tabular}} \\
\hline \multicolumn{11}{|c|}{ Boost Pressure (FUEL, RPM) /mBAR } & & - \\
\hline $\mathrm{mg} / \mathrm{str}$ & 0 & & 10 & & 20 & & 30 & & 40 & & & \\
\hline rpm & & 5 & & 15 & & 25 & & 35 & & 45 & & \\
\hline 0 & 198 & 198 & 198 & 198 & 198 & 198 & 198 & 198 & 198 & 198 & & \\
\hline 21 & 1100 & 1100 & 1100 & 1115 & 1170 & 1220 & 1400 & 1400 & 1400 & 1400 & & \\
\hline 1008 & 1100 & 1100 & 1100 & 1115 & 1170 & 1220 & 1400 & 1400 & 1400 & 1400 & בו & \\
\hline 1260 & 1100 & 1100 & 1100 & 1115 & 1260 & 1360 & 1645 & 1645 & 1645 & 1645 & 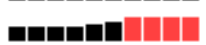 & \\
\hline 1491 & 1100 & 1100 & 1100 & 1185 & 1277 & 1414 & 1698 & 1872 & 1872 & 1872 & 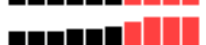 & \\
\hline 1743 & 1100 & 1100 & 1105 & 1200 & 1393 & 1593 & 1866 & 2033 & 2033 & 2033 & & $=$ \\
\hline 1911 & 1110 & 1110 & 1115 & 1230 & 1458 & 1696 & 1971 & 2150 & 2150 & 2150 & & \\
\hline 2058 & 1130 & 1130 & 1135 & 1279 & 1511 & 1786 & 2034 & 2193 & 2193 & 2193 & & \\
\hline 2247 & 1156 & 1156 & 1165 & 1305 & 1591 & 1851 & 2057 & 2193 & 2193 & 2193 & & \\
\hline 2499 & 1165 & 1165 & 1220 & 1345 & 1660 & 1908 & 2057 & 2193 & 2193 & 2193 & & \\
\hline 2830 & 1180 & 1180 & 1280 & 1391 & 1670 & 1915 & 2057 & 2193 & 2193 & 2193 & & \\
\hline 3507 & 1200 & 1200 & 1280 & 1400 & 1610 & 1780 & 2057 & 2193 & 2193 & 2193 & & \\
\hline 3990 & 1200 & 1200 & 1280 & 1385 & 1550 & 1695 & 2030 & 2172 & 2172 & 2172 & & \\
\hline 4242 & 1225 & 1225 & 1285 & 1385 & 1530 & 1664 & 1983 & 2070 & 2070 & 2070 & & \\
\hline 4494 & 1250 & 1250 & 1290 & 1389 & 1510 & 1630 & 1907 & 1934 & 1934 & 1934 & ]1] & 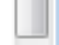 \\
\hline 4746 & 1275 & 1275 & 1295 & 1389 & 1500 & 1600 & 1793 & 1793 & 1793 & 1793 & | & \\
\hline
\end{tabular}

Fig. 13. Modified fuzzy-logic map for the pressure in the intake manifold

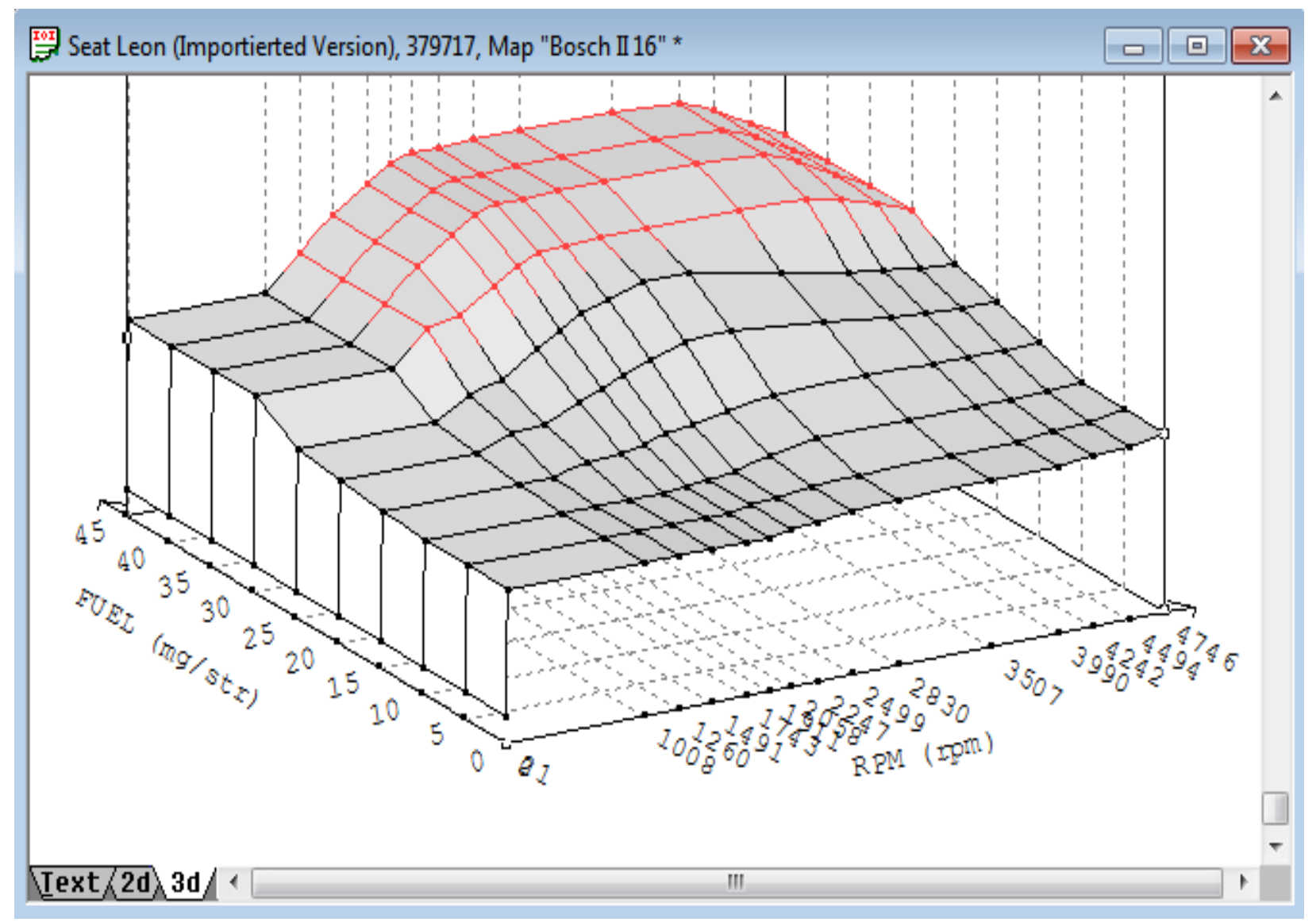

Fig. 14. Modified control surface for the pressure in the intake manifold 